\title{
FEUDALISM IN THE NOVELS OF EMINENT NOVELIST HOMEN BORGOHAIN FROM DOMAIN OF ASSAMESE LITERATURE
}

\author{
Ashim Chutia \\ Research Scholar, Department of Assamese, \\ Gauhati University, Assam, India
}

\begin{abstract}
Feudalism is a socio-economical concept. There are two groups involved in. one is BHU SWAMI i.e., owner of land and the other being BHUMIHEEN i.e., the landless folk. Land owners perform power to possess the land and the landless people make no stone unturned to plough the land in order to reap harvest. In exchange of it they earn a tiny fraction of crops they produce.

Federal system is a vast chapter in history of Assam. The base of it was formed intensively during reign of Ahom kingdoms. But the exploiting and atrocious ways of the federal systems pushed Ahom dynasty towards adversities. Muamuriah revolution was called for against this Ahom feudalism. Though some religious issues were causes for this revolution, it was, chiefly by the common people as a protest against rising oppression and exploitation. After Assam came under the British rule the age old system offeudalism crumbled into dust. British had kicked off new ways for administration and hence they did create new portfolios. And in those new posts British appointed those aristocratic men who nurtured sense of feudalism.

Well known Assamese scholar, Prafulla Mahanta distributed these rules into two parts : in the first group there are village Moujadars, Mandals, The head of villages, Pandits, Satradhikaars who did not need to pay tax and the Priests; the second part did comprise of Magistrate, Judiciary officials, Peskar, Clerks, Policeman, Advocates and Doctors.

In rule of these two parties the working people had to face much act of brutality as far as feudalism was concerned. There was a famine that rose in that system.

This research paper deals with the analysis that how Assames novelist Homen Borgohain did portray this epoch of feudalism in his works
\end{abstract}

Keywords: Bhu Swami, Moujadars, Mandals, ADHI, Kaivarta.

Cite this Article: Ashim Chutia, Feudalism in the Novels of Eminent Novelist Homen Borgohain From Domain of Assamese Literature, International Journal of Management, 11(9), 2020, pp. 916-921.

http://iaeme.com/Home/issue/IJM?Volume=11\&Issue=9 


\section{INTRODUCTION}

Economy plays an important role while building infrastructure of a society. Way of living according to social structure, communal status, economical skills, standard of living, sense of morality, art and awareness all these are controlled by economy. Looking into these elements one could comprehend the socio economical character of a community.

Literature mirrors society at large. In novels, especially we get a detail insight of the social life and behaviour and so is in case of social novels.

This paper vows for depicting Homen Borgain, the eminent Assamese author and his novels after Second World War dealing with socio economical life styles. The socio economical concept encompasses federal social system, federal administration and people suffering a lot from it, plight of those who did support to feudalism, revolution of the oppressed ones, the decline of federalism and all these are being discussed in this paper. Above all lives of poor folks striving hard to live have been given importance here in.

\section{FEATURES OF FEUDALISM AND A GLIMPSE OF ITS STRUCTURE FROM AHOM REIGN TO THE TIME WHEN WAR WAS CALLED FOR}

Ahom dynasty was on feudalism, the officials, game or all pastime activities, the PAIK system on hard physical labour all these were ground of that feudal system (1). Much before Ahom governance there was a healthy relation between the local agriculture and feudalistic land system during reign of BARMAN, XALSTOMBHO and PAAL (2). This hereby bears the truth of the observation that Feudalism has an age old history in Assam and it was ripe during Ahom governance. But it was seen that feudalistic approach made Ahom administration a complete failure in the long run (3). It is already been mentioned that Muamuriah revolution was there at that time as a protest to Ahom feudalism. Religion, though was an underlying factor for the phenomenon, the agitated common folks kicked it off for the uninterrupted barbarism they had to bear (4). The British rule created havoc in the middle aged feudalism. They introduced new systems for administration and to make it vibrant with meaningful authoritative control British created new administrative posts. Well known Assamese scholar, Prafulla Mahanta distributed these rules into two parts : in the first group there are village Moujadars, Mandals, The head of villages, Pandits, Satradhikaars who did not need to pay tax and the Priests ; the second part did comprise of town based Magistrate, Judiciary officials, Peskar, Clerks, Policeman, Advocates and Doctors (5). The spic-and-span social structure could not rub out the feudalistic bent of mind on their part entirely. They were, in fact feudalistic land owners in a noncompromising way hiding in British authority.

\section{FEUDALISM REFLECTING IN THE NOVEL PITA PUTRA BY HOMEN BORGOHAIN}

Here comes a view on Homen Borgohain,s novel PITA PUTRA - ' a new class of people was found who like Sibnath or Saikia Moujadar did allow farmers to cultivate in their land on barter system which was typically known as ADHI." They took lands on mortgage in cheap prices, they were none but the Advocates, Mandals the newly appointed class who became land owner in tricky way" (6). To buy land at low cost or to deal with through barter system i.e., Adhi were their chief concern. This middle class people exercised feudalism and simultaneously played role against the interests of poor cultivators (7). In this novel chiefly the class of people living on cultivation who have been victimized in feudalistic administration are delineated. The novel has four parts and the protagonist Sibnath is owner of a vast spread plot of land, hence he is a Jaminder in the village.one fourth of the villagers cultivate in his land in barter system i., e., 
taking Adhi. The nearby village of Kaivarta people work as farmhand. Besides Sibnath there are one or two landowners in the village. But amount of workers is larger than that of land holder, for it workers are not been paid off satisfactorily be it the money or the corpse. The landless poor farmer Kotia is described this way in the novel, "the cloth he wears hardly covers up his lower part of body and those dirty, ragged clothes were insufficient to cocoon themselves (9)." Taking advantage from such poor men a class of self-seekers ruled over the economy. In the novel Rev Mahajon came and started his economical empire. With the government Rev Mahajan and Keshab Mandal came together to distribute the relief but excluded the DalDalits. Just like this in the medieval era on the land of the headmen landless farmers could not get their due and justice even labouring hard. And the newly created richest or the service oriented class by the administration system has created havoc in their existence.

In novels of Homen Borgohain, feudalism reflects this way.

\section{AGONY ON THE FEUDALISTIC CHARACTERS}

The central character, Sibnath, though, is penned in high feudalistic sentiment he is not seen with inner conflicts simultaneously. He developed sense of pity towards those Kaivarta people who did not have a hut apart from the land where their house stood, who have been suffering a lot from years due to poverty falling prey to hatred, anguish and ignorance. His mind questions. Is this not enough in case of those poor people? Sibnath with storm of thoughts within himself couldn't protest against the prevailing social atrocity. He is compelled to accept the rule and administration as it is. He suffers in his thoughts, he ponders over the problem and realises that as those people are landless opportunists like him are able to earn benefit and live like monarch. As those people earn land what would be with these kings, Sibnath contemplates deeply. To sum up plight of Kaivarta people ignites conflict in Sibnath. Sibnath on the other hand is afraid of the forthcoming independence of the country which would erase out feudalism, he articulates, "I aspire for independence of my motherland but really do I want it on part of Kaivarta people from me? (10)"

\section{DECLINE OF FEUDAL SYSTEM}

The dream of Sibnath depicted in the very first chapter of the novel is nothing but a clarion call of the decline of feudalistic social structure. The dream was: ' all from Kaivarta class have risen above poverty with wealth and all, none from them does approach Sibnath to be employed neither as cultivator nor farmhand, no one come to him looking for land to tilt(11)'.

In the following chapter of the novel how a new wave of transformation engulf Mahghuli, the village of Sibnath is described. While chanting Husori the public decided not to discriminate the rich from the poor nor there would be any favouritism and the irrespective of any class of people husori will be sung from one to another corner of the hamlet. In this matter Sibnath was given priority earlier as a host, therefore, the changed system has attacked his social position vehemently. The dream in his sleep depicted in the first chapter is now a harsh reality Sibnath is bound to encounter in the second chapter (12).

In the third chapter Sibnath appears to be worst sufferer in some adverse situation. It has been fifteen days from Bohag with not a single man approaching him in need of any plot of land for ploughing. The reason behind it is that the government has built up manmade dam by the river bank allowing the Sapori for cultivation of Xali. This socio cultural change has brought pleasure to the poor and simultaneously it has been the cause of downfall of that opportunist class of people who lived on hard labour of poor folks.

In the fourth chapter Sibnath began to tremble with fear very intensely. His hopes, aspirations and all are in threshold to decay. 'sibnath could understand that in the hands of Kalinath the age old glory of his family would come to its end and his social fame of aristocracy, 
power as landlord all will be vanquished by none other than Kalinath (13).' That Kalinath vouches for working towards progress of society was the chief cause to wipe out evil motives in Sibnath.

\section{REVOLT AGAINST FEUDALISM}

It is a story of conflict between two generations that is seen in PITA PUTRA. This conflict rises from the deference between past and present values in human. When the villagers had decided to chant Husori irrespective of all cast and creed from one end to the other of the village Sibnath met with ultimate on his disloyal aristocracy. This was actually an expression of rebellion that the people had suppressed for so long. His elder son, Gaurinath even did not care for his father's essence of feudalism going to marry the girl from Kaivarta class of people. Gaurinath wrote in his letter to father, 'when a father with his love and logic is unable to compel him to abide by his words, the father uses economic power as last weapon. .My father such tool might have worked in old years but is of no use in our modern epoch (14).'

\section{THE FEUDALISM DEPICTED IN THE NOVEL NAMED HALODHIYA SORAYE BAUDHAN KHAI}

In this novel the protagonist Rokheswar falls prey to federal system. The wealthiest landlord of the village, Sanatan Sarma takes the only asset of Rokheswar, his land under him. To deceive the poor and to occupy land of farmers were important characteristics of the federal system. Here Sanatan Sarma is also an epitome of feudal king. The landless Rokheswar had to face with indefinable poverty. While brawling for his rights Rokheswar sold all his possessions, gold, cattles and all to fight in the court.

The new economic order implemented by the British governance created another breed of clerks and officials who could be bought with bribe. This was actually the result of the attempt of keeping the middle class people satisfied. The rich and powerful persons like Santan Sarma could earn respect from the officials only for the wealth they had. This is neatly an encouragement towards feudalism.

The corrupt postman, mandal, clerks, land owner Santan Sarma and all equipped with feudalistic sentiment has brought people like Rokheswar to his knees. When he was in need of money to re-open the case in court he had to make his elder son servant in house of village head.

In the later part of the novel the duality of feudalism is depicted in new time with new dimension. The land owner Santan Sarma had joined socialist group and campaigning himself he announced, "The cluster of mahajan has taken possession of all plots of land. As the election is past taking all of it over will be distributed among the poor landless farmers (15).

With a desire of earning a vote the enemy Santan Sarma made his entry in the house of the victim Rokheswar. ' but the fear and submission towards the rich and the mighty has been common for people like Rokheswar for centuries, in spite of his other emotions Rokheswar submitted to him overwhelmed with fear( 16).

From this part of the novel we could understand that even after the federal system collapsed products of it like Santan Sarma still prevailed and still continued to affect the lives of poverty stricken population.

\section{MOTSHYAGANDHAA DEALING WITH FEUDALISM}

This novel exhibits how corrupt economy from time to time has brought catastrophic distress in here and now as far as human dignity is concerned. The Kaivarta class of people who have 
been looked down upon by the high hierarchy of Hindus is treated sympathetically in this novel. This is only class of people who is oppressed and landless. The high class of Hindus are landlords. Though the novelist is not prompt enough to mention it, the theme is clear what he has penned, 'if he marries me I will be the mistress of those four pieces of land, Xalitoli (17).' This is the voice of poor Kaivarta girl, Kamala. Kamala, being trapped by Maniram of Ahom community and who performs sexual relation with Kamala and has made her pregnant and when Menoka utter indecent words to her speaks this.

This way, a group of people living with the ideas of the federal system has been using it to exploit and rule over the people from lower-class. The communalism has its roots in feudalism, so it is also a very narrow and harmful for society in terms of progress and human equity. Because the lords of the federal system knew it well that if they didn't rule with discrimination, disrespect and neglect their social status and respect would collapse.

But characters like Manoka did not accept such traits of the federal rule. Instead she had rejected it and announced revolt against it. She, for that reason didn't support Maniram to abort the child in Kamala, though kamala was pregnant being involved in physical relation with Maniram unlawfully. She in this respect said, 'have you taken a girl from Dom for a mere toy that it can be thrown off after you are done playing (18),

Towards the end of the novel she called out so that a passer-by could hear, 'I am not pulling you all down, one of you has been lifted up, make it sure, days are few for you (19),'

This uprising of Manoka is against communalism as well as the knotted structure of feudalism.

\section{CONCLUSION}

Among this three discussed novels the one named Pita Putra has the timeline before and after the war spanning over a period of three decades, the other two novels also have their premise set around the war. In all of the works feudalistic socio economic system has been given a trailblazing aspect. The downfall of it had started from the time of Ahom and was completely decayed just after British came to rule. British were instrumental to switch on capitalism as a result of which Assamese middle class people took birth. From this class of people Jaminder, mandal, Mahajon and all such men exercised feudalism in their activities. Like them all of the town based servicemen were land lords in disguise.

As have been discussed already, in the novel, Pita Putro characters like Rev Mahajan, Sibnath, Keshab Mandal and in the novel, Halodhiya Soraye Baudhan Khai characters like Santan Sarma, Dimbeswar Mandal, Advocate, Clerk all are epitome of feudalism. They somehow rule the landless farmers or the minor Kaivarta class of people. They have fetched land from poor class of people with might and main putting them down into poverty line. In spite of their hard labour the poor farmers did not get the justice in matters of money or anything else. Even the kaivarta girl, Kamala has fallen victim of illicit sexual desire of feudalist people.

Characters like Sibnath undergoes sever agony for it but cannot make up his mind to accept the change from it.

Female characters like Manoka, somewhere gives a clarion call for revolt against it. Before independence the new socio economic system has brought changed into the society throwing away the age old feudalistic sentiment. Gaurinath, the elder son of Sibnath has given a Kaivarta girl honour as his wife. This has torn apart his father's rigid authority and daunting pride. On the other hand the aristocratic Ahom lad Maniram has to serve in his in laws 'house. 
On the initiation of government the landless farmers had got plots of land for which the so called land owners suffered a lot economically. Their empire crumbled.

To sum up the poor class of people are given raw deal of life in every phases of time, though there is change in social system the conflict between the autocrat and the oppressed ones never meet its end.

The change in human mind is must amend these age old customs. Prior to independence it was like venom in human sentiment as penned down by Homen Borgohain in his novels sharply.

\section{REFERENCES}

[1] Jatindra Kumar Buragohain (2005), “Axomor Xomajik Rupantor Aru Modhyasrenir Bikash”, 129.

[2] Prafulla Mahanta (2009) “Abatarnika', “Axomia Modhyobitosrenir itihax”, 12.

[3] Gitashee Tamuli, 'Axomia Upanyaxot Krixok-Jibonor Kothokota', Nogen Thakur (2000, ed.), "Exo years of assamese novels", 188.

[4] Prafulla Mahanta 'Abatarnika', "Axomia Modhyobitosrenir itihax”, 150.

[5] Homen Borgohain (2009), "Pita Putra", 51.

[6] Homen Borgohain (2009), "Pita Putra", 46.

[7] Homen Borgohain (2009), "Pita Putra", 60.

[8] Homen Borgohain (2009), "Pita Putra", 59.

[9] Jayanta Kumar Bora (2009), "Xubalar pora Moshyogondo loi”, 56.

[10] Homen Borgohain (2009), "Pita Putra", Pg-297

[11] Homen Borgohain (2009), "Pita Putra", Pg-51

[12] Homen borgohain (1988), "Halodhiya Soraye Baudhan Khai”, 122.

[13] Homen borgohain (1988), "Halodhiya Soraye Baudhan Khai”, 133.

[14] Homen borgohain (2000), "Matshyagandhaa", 58.

[15] Homen borgohain (2000), "Matshyagandhaa", 69-70.

[16] Homen borgohain (2000), "Matshyagandhaa", 80.

[17] Madan sharma, "Humen Borgohai'r Upanyax", Nogen Thakur (2000, ed.), "Exo Years of Assamese Novels", 519. 